nation, and are placed in the British Museum. The corresponding discoveries in the French zone of occupation, further west, are summarised by Capt. Ch. Picard, now director of the French Archæological School at Athens. The finds in

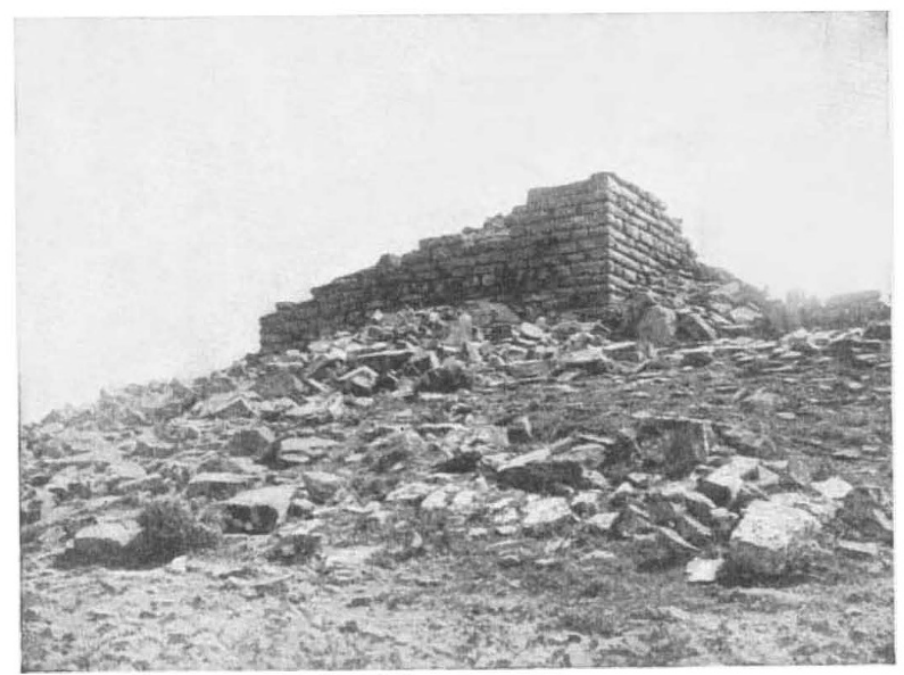
Frg. 3.-Ruins at Hagia Sophia in I.emnos. From "The Annual of the British School

both zones were of all periods. The most novel illustrate the earlier periods from the Neolithic to the early Iron age, revealing new distributions of pottery styles, and types of primitive figurines, and raising a number of questions which can only be solved by systematic excavation as soon as local conditions allow.

Mr. M. N. Tod publishes twenty-five Greek inscriptions from the same district, and Mr. A. M. Woodward adds a note on the Byzantine castle of Avret-Hissar (Gynaikokastro).

Other war surveys are published by Mr. F. W. G. Foat, who was in charge of " educational work on topography and archæology" at the Y.M.C.A. rest camps in ancient Doris, and on the island of Lemnos by Mr. F. L. W. Sealy, who appends also notes on birds and fishes observed there. Mention should also be made here of Mr. Hasluck's paper on "The Rise of Modern Smyrna."

Further afield, Mr. S. Casson, who was for a while in charge of the Salonica Museum, made good use of a flying visit to the Caucasus and Western Turkestan to describe an extensive series of prehistoric mounds, and to throw fresh light on Herodotus' account of the ancient routes eastward from Scythia.

Other papers, such as those on the fictitious legend of "Saint Gerasimos and the English Admiral" and on "The Folklore of a Turkish Labour Battalion," illustrate more special aspects of research under war conditions, and also the great variety of subjects which are studied by members of the British School at Athens.

\title{
The Annular Eclipse of April 8.
}

\section{By Dr. A. C. D. Crommelin.}

$\mathrm{T}^{\mathrm{H}}$ E occurrence of a central solar eclipse within the limits of the British Isles is a somewhat rare event. On the average, one total eclipse is visible here in seventy years, and one annular eclipse in about sixty years. It is, therefore, note. worthy that the decade now commencing supplies examples of both. There has been no British total solar eclipse since $\mathbf{I}_{72}$, the interval being about three times the average; the last annular eclipse was in $185^{8}$. After the present decade there will be totalities in 1999 and 2090, and annularity in 2093 .

The central line on April 8 passes across South Uist, just misses Cape Wrath, and then runs a few miles north-west of the Shetlands. The south limit of annularity enters Scotland near Ardnamurchan Point, and runs nearly parallel to the Caledonian Canal, emerging near Wick. Thus practically the whole of the counties of Ross and Cromarty, Sutherland and Caithness, and a corner of Inverness, together with the Outer Hebrides, Skye, and the Orkneys and Shetlands, will enjoy the annular phase.

The eclipse occurs about 9 a.m., the sun's altitude being about $23^{\circ}$; the duration of annularity is $\operatorname{Ir}$ r sec., the width of the annulus of sunNO. 2678 , VOL. IO6] light being $26^{\prime \prime}$. This implies that $1 / 19$ of the sun's disc will remain uncovered; in other words, the illumination will exceed normal sunshine on the planet Jupiter. Remembering what a resplendent object Jupiter appears in the night sky, it will be seen that there will be nothing approaching darkness. Venus will doubtless be readily visible, about $20^{\circ}$ east of the sun; it will be a slender crescent, inferior conjunction occurring a fortnight later. The only other object that may possibly be visible is Vega, which will be high in the west, three hours past the meridian.

Dr. J. K. Fotheringham, who has made a special study of the records of ancient eclipses, intends to examine the question of its visibility, as it is important to know what degree of solar obscuration is implied by the frequently recurring phrase, "Stars were visible." It is used, for example, by Thucydides with reference to an eclipse which was not total anywhere.

As regards useful observations that may be made in the coming eclipse, the exact times of the beginning and end of annularity can be accurately noted. especially by the method of projection upon a white screen; they serve to correct the position of the moon; those who cannot deter- 
mine absolute time can still do good work by timing the exact duration of annularity; this applies especially to observers fairly near the limit of annularity. Prof. Newcomb found numerous records of this kind, made in England during the total eclipse of $17 I_{5}$, which enabled him to correct Hansen's value of the centennial motion of the moon's node. Photographs taken about mid-eclipse, on as large a scale as possible, would be of value for determining the difference of the diameters and ellipticities of sun and moon.

Useful spectroscopic work car also be done, the diminution of sky-glare being of service in photographing the prominences or reversing layer. The British Astronomical Association, which has experience of a great number of eclipses, is prepared to organise work if a sufficient number of observers send in their names.

It is possible to reach observing stations by rail, either on the line to Wick and Thurso, or on that running westward from Dingwall to Loch Alsh (for Skye); the journey from London to the eclipse zone is in the neighbourhood of twenty-two hours, and the return fare (third class) in the neighbourhood of 87 . at present rates. The season is probably too early for the steamboat services, otherwise these would afford a ready means of reaching observing stations on the mainland or islands.

Besides astronomical work, the eclipse affords opportunities for at least three other studies: (I) Meteorological. The temperature is directly affected, and there are frequent indirect effects on barometer, wind, and cloud formation. (2) Magnetical. The work of the Carnegie Institution of Washington, under Prof. L. Bauer, has established a connection between eclipses and the elements of terrestrial magnetism. Such a connection is in no way surprising, for the diurnal variation in these elements has long been known, so it is to be expected that the interposition of the moon should act similarly to the interposition of the earth during the night hours. (3) Wireless telegraphy. A notable improvement in the clearness of signals has been observed during eclipses, which is again analogous to what happens during the hours of darkness. Advantage might be taken of this to make time comparisons for longitude about the time of greatest eclipse. The eclipse is large enough for this purpose throughout the British Isles. The magnitude at Edinburgh is 0.95 ; Dublin, 0.94; Oxford and Cambridge, 0.89 ; and Greenwich, 0.88 .

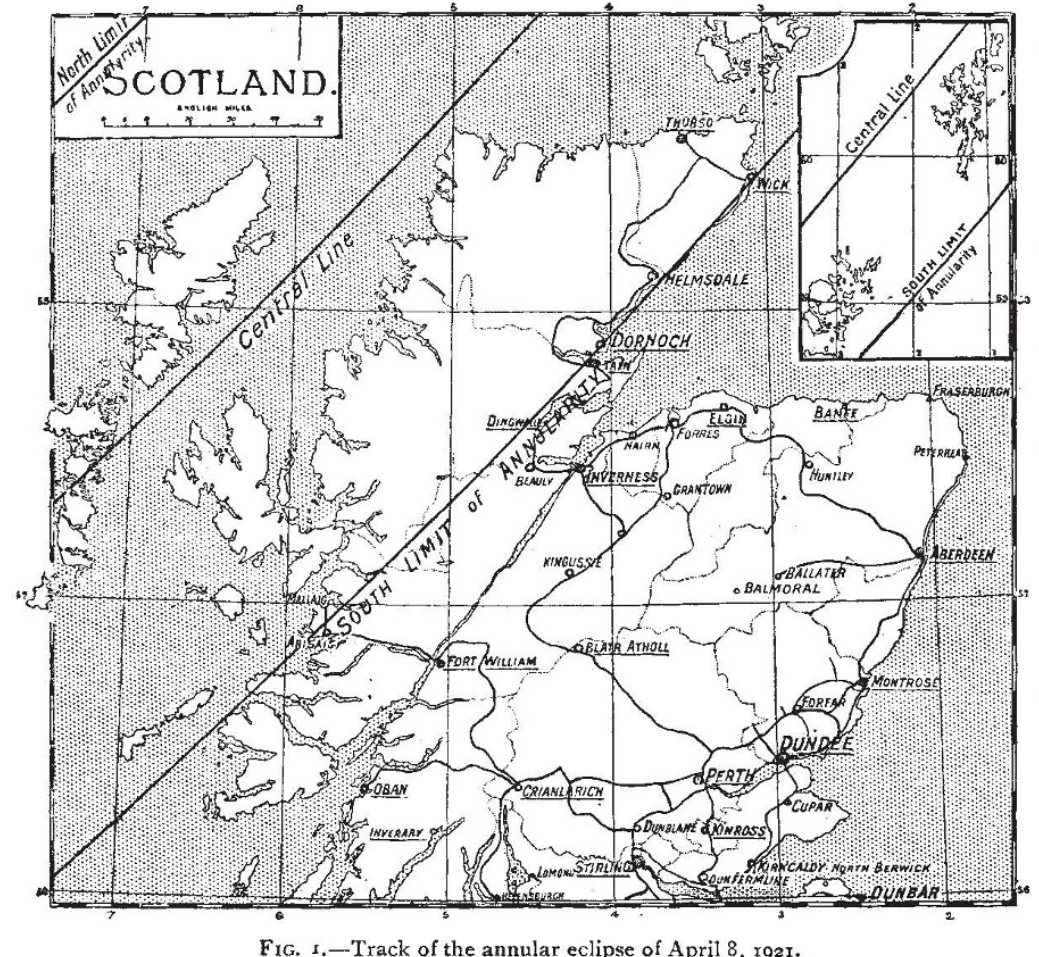

There will be a total solar eclipse in England and Wales on June 29, I927 (civil). The central line will run from near St. David's Head to near Whitby, where the sun will have risen about $I \frac{3}{4}$ hours, and totality will last $24 \mathrm{sec}$. At the total eclipse of January 24, 1925, the track of totality will graze the Western Hebrides, but with a very low sun. It will be necessary to go to the neighbourhood of New York for effective observations on that accasion.

\section{Obituary.}

Prof. Emile Bourquelot.

$\mathrm{B}^{\mathrm{Y}}$ $Y$ the death of Emile Bourquelot, Professor of galenical pharmacy in the University of Paris, science has sustained an irreparable loss. Born in a small village in the Ardennes in $185^{2}$, Bourquelot was apprenticed in a pharmacy in Sedan while the town was still occupied by the Germans. He afterwards became chief pharmacist in the Hôpital Laeonec, and then successively NO. 2678 , VOL. I06] assistant professor and professor of galenical pharmacy in the Ecole Supérieure de Pharmacie, now the faculty of pharmacy in the University of Paris. Bourquelot at once devoted himself to the investigation of various pharmaceutical problems, but gradually restricted himself almost entirely to the study of the enzymes occurring in drugs and various plants, their action and the changes brought about by them in the constituents of 